\title{
PASANG SURUT KEBEBASAN PERS DI INDONESIA
}

\author{
Satrio Saptohadi \\ Fakultas Hukum Universitas) enderal Soedirman Purwokerto \\ E-mail: satrio.saptohadi@unsoed.ac.id
}

\begin{abstract}
In the New Order of the press regulated by Law No. 11 Year 1966, Law No. 4 Year 1967 and Law no. 21 Year 1982 which is a product of the repressive Soeharto regime, whereas in the era of reform after the resignation of Suharto's life enacted press Law No. 40 Year 1999 about the Press is full of euphoria. During the New Order's authoritarian press system produces under the guide of Pancasila press system that is free press and responsible, to the effect of press freedom in a way that is very restrained by bridle and thrown into prison their anti-government. In the Reform era of the press leading up to the liberal press system that is with the euphoria of freedom that went too far because there is no regulation of the repressive provisions.
\end{abstract}

Key words: New order, the reform era and freedom of the press.

\section{Abstrak}

Di masa Orde Baru pers diatur dengan Undang-undang No. 11 Tahun 1966, Undang-undang No. 4 Tahun 1967 dan Undang-undang No. 21 Tahun 1982 yang merupakan produk rezim Soeharto yang represif, sedangkan di era Reformasi setelah lengsernya Soeharto kehidupan pers diberlakukan Undang-undang No. 40 Tahun 1999 tentang Pers yang penuh dengan euforia. Selama masa Orde Baru menghasilkan sistem pers yang otoriter dengan kedok sistem pers Pancasila yaitu pers yang bebas dan bertanggung jawab, sehingga akibatnya kebebasan pers sangat dikekang yaitu dengan cara breidel dan menjebloskan ke penjara yang anti pemerintah. Di era Reformasi sistem pers menuju ke sistem pers liberal yaitu dengan adanya euforia kebebasan yang kebablasan karena tidak ada lagi ketentuan regulasi yang represif.

Kata kunci : Orde baru, era reformasi dan kebebasan pers.

\section{Pendahuluan}

Jatuhnya Presiden Soekarno dari tampuk kepemimpinan nasional, membuat Jenderal Soeharto mulai memegang kendali pemerintahan dan masa tersebut disebut sebagai masa Orde Baru. Di masa ini konsentrasi penyelenggaraan pemerintahan negara menitikberatkan pada aspek stabilitas politik dalam rangka menunjang pembangunan nasional. Untuk mendukung terwujudnya stabilitas politik dalam rangka pembangunan nasional, maka dilakukanlah upaya-upaya pembenahan sistem ketatanegaraan dan format politik dengan menonjolkan pada hal-hal berupa: pertama, Konsep Dwi Fungsi $A B R I$ digunakan sebagai platform politik Orde Baru. ABRI (militer) tidak hanya berfungsi sebagai alat pertahanan negara atau mesin perang dalam rangka menjaga kedaulatan negara, melainkan juga memainkan peran sosial politik dan terlibat dalam pengambilan keputusan-keputusan politik; kedua, pengutamaan Golongan Karya; ketiga, magnifikasi kekuasaan di tangan eksekutif; keempat, diteruskannya sistem pengangkatan dalam lembaga-lembaga pewakilan rakyat; kelima, kebijakan depolitisasi khususnya masyarakat pedesaan konsep masa mengambang (floating mass); dan keenam, kontrol Arbriter atas kehidupan pers. ${ }^{1}$

Konsep Dwi Fungsi ABRI secara implisit sebenarnya sudah dikemukakan oleh Kepala Staf Angkatan Darat, Mayjen Abdul Haris Nasution pada tahun 1958. Menurut Nasution Dwi Fungsi ABRI merupakan konsep jalan tengah. Prinsipnya menegaskan bahwa militer

B. Hestu Cipto Handoyo, 2009, Hukum Tata Negara Indonesia, Yogyakarta: Atmajaya, hlm. 106. 
atau tentara tidak terbatas pada tugas profesional militer belaka, melainkan juga mempunyai tugas-tugas lain di bidang sosial politik. ${ }^{2}$ Dalam perkembangannya, Orde Baru (19661998) diawali dengan gagalnya pemberontakan G 30 S/ PKI pada tahun 1965. Kemudian adanya Surat Perintah Sebelas Maret (Supersemar) 1966 dari Presiden Soekarno kepada Letjend Soeharto. Pemerintah Orde Baru bertekad untuk mempertahankan dan melaksanakan Pancasila dan UUD 1945 secara murni dan konsekuen dalam kehidupan bermasyarakat, berbangsa dan bernegara. ${ }^{3}$

Kebijakan Orde Baru mendukung sepenuhnya pers Pancasila untuk berperan kembali dalam masyarakat menyuarakan aspirasi rakyat yang sebelumnya dibungkam oleh Soekarno (Masa Orde Lama). Pada awal Orde Baru, pers aktif mengamankan dan membantu pemerintah dalam menertibkan gejolak serta peristiwa yang ada dalam masyarakat, baik dalam lingkup politik maupun dalam lingkup kemasyarakatan sebagai kelanjutan dari sisa-sisa antagonisme Orde Lama. ${ }^{4}$

Proses perkembangan dan peranan pers nasional kemudian dibentuk suatu undang-undang yang mengatur keberadaan dan peranan pers nasional. Tujuan utama dari undang-undang tentang ketentuan pokok pers untuk memberikan jaminan hukum/kedudukan hukum pers agar dapat menjalankan fungsinya sebaikbaiknya dan dapat melaksanakan tugas kewajibannya, serta menggunakan hak-haknya untuk terwujudnya pers nasional yakni Pers Pancasila.

Peraturan perundang-undangan yang mengatur tugas pemerintah dalam membina pertumbuhan dan perkembangan pers adalah per-

Ali Moertopo, 1982, Strategi Pembangunan Nasional, Jakarta: CSIS, hlm. 190; Lihat dan Bandingkan dengan Sumali, "Urgensi TNI di Bingkai Konstitusi Dalam Perspektif Yuridis Politis", J urnal Hukum Respublica, Vol. 3 No. 1, Tahun 2003, Pekanbaru: Fakultas Hukum Universitas Lancang Kuning, hlm. 49-64.

3 Nurhasan, "Pasang Surut Penegakan HAM dan Demokrasi di Indonesia", J urnal II mu Hukum Litigasi, Vol. 6 No. 2, J uni 2005, Bandung: Fakultas Hukum Universitas Pasundan, hlm. 217.

4 Adhi Priamarizki, 2008, Demokrasi dan Kebebasan Pers, Vol. 5 No. 1, Tahun 2008, Jakarta: J urnal Sentris Pusat Pengkaji Pers, hlm. 45. tama, Tap MPR No. 11/1983 tentang GBHN, mengenai Penerangan dan Media Massa. Tap ini merupakan perintah MPR kepada Presiden sebagai Mandataris MPR untuk dilaksanakan; kedua, Undang-undang No. $11 / 1996$ J is Undangundang No. 4 Tahun 1967 dan Undang-undang No. 21 Tahun 1982 tentang Undang-undang Pokok Pers yang telah diperbaiki dan disempurnakan; ketiga, Peraturan Pemerintah sebagai peraturan organiknya dari Undang-undang Pokok Pers tersebut, seperti di antaranya PP No. 19/1970 tentang Dewan Pers; keempat, Beberapa dari Peraturan Menteri Penerangan, seperti di antaranya Peraturan Menpen No. 01/ Per/ Menpen/ 1967 tentang Wartawan, Peraturan Menpen No.02 / Per/Menpen/ 1969 tentang Penerbitan Pers dan Peraturan Menpen No. 01/Per/Menpen/ 1984 tentang Surat Izin Usaha Penerbitan Pers (SIUPP)

Presiden Soeharto meletakkan jabatannya pada tanggal 21 Mei 1998 dan diganti oleh Wakil Presiden BJ. Habibie. Pergantian jabatan tersebut menurut sementara pihak merupakan langkah konstitusional, sebab Pasal 8 UUD 1945 telah menegaskan bahwa jika Presiden mangkat, berhenti atau tidak dapat melakukan kewajibannya dalam masa jabatannya, ia digantikan oleh Wakil Presiden sampai habis waktunya. Dengan tumbangnya rezim Orde Baru, maka dimulailah penataan sistem ketatanegaraan menuju konsolidasi sistem demokrasi di Indonesia. Konsolidasi yang paling penting di sini tidak lain adalah dengan melakukan perubahan dan penggantian berbagai Peraturan Perundang-undangan yang dirasa tidak memberikan ruang gerak bagi kehidupan demokrasi. $^{5}$

Tahun 1998 gerakan reformasi berhasil menumbangkan rezim Orde Baru. Keberhasilan gerakan ini melahirkan peraturan perundangundangan sebagai pengganti peraturan perundang-undangan yang menyimpang dari nilainilai Pancasila, yaitu Undang-undang No. 40 Tahun 1999 tentang Pers. Peraturan ini berbeda dengan UU No. 11 Tahun 1966 jo UU No. 4

Lihat M. Nur Hasan, "Tantangan Demokrasi di Indonesia", J urnal Aspirasi, Vol. 16 No. 1, Juli 2006, Jakarta: Magister Ilmu Hukum Trisakti, hlm. 33-40. 
Tahun 1967 jo UU No. 21 Tahun 1982 yang memberi kewenangan kepada pemerintah untuk mengontrol sistem pers, UU No. 40 Tahun 1999 lebih memberi kewenangan kontrol kepada masyarakat antara lain terletak pada pasal 15 ayat (1) yang menyatakan bahwa "dalam upaya mengembangkan kemerdekaan pers dan meningkatkan kehidupan pers nasional, dibentuk Dewan Pers yang independen". Adapun Pasal 17 menyatakan bahwa masyarakat dapat melakuan kegiatan untuk mengembangkan kemerdekaan pers dan menjamin hak memperoleh informasi yang diperlukan, kegiatan tersebut berupa memantau dan melaporkan analisis mengenai pelanggaran hukum, etika dan kekeliruan teknis pemberitaan yang dilakukan oleh pers; dan menyampaikan usulan dan saran kepada Dewan Pers dalam rangka menjaga dan meningkatkan kualitas pers nasional. ${ }^{6}$

Agar penyelenggaraan pemerintah yang baik dapat tercapai maka dibutuhkan peran pers yang bebas berekspresi dan berinformasi merupakan wujud dari kemerdekaan pers yang merupakan salah satu wujud kedaulatan rakyat dan menjadi unsur yang sangat penting untuk menciptakan kehidupan bermasyarakat, berbangsa dan bernegara yang demokratis. ${ }^{7}$

Secara konsititusional, kemerdekaan menyatakan pikiran dan pendapat (HAM) di Indonesia dijamin dalam UUD 1945 setelah amandemen, yaitu Pasal 28 yang menyatakan bahwa kemerdekaan berserikat dan berkumpul mengeluarkan pikiran dengan lisan dan tulisan dan sebagainya ditetapkan dengan undang-undang. Pasal 28 F yang menyatakan bahwa Setiap orang berhak untuk berkomunikasi dan memperoleh informasi untuk mengembangkan pribadi dan lingkungan sosialnya, serta berhak untuk mencari, memperoleh, memiliki, menyimpan, mengolah dan menyampaikan informasi dengan menggunakan segala jenis saluran yang tersedia.

http:// adiprakosa. blogspot. com/ 2008/ 01/ sistem-persindonesia. html, hlm. 7, diakses tanggal 9 Oktober 2009 M. Djamil Usamy, "Kebebasan Pers dan kaitannya dengan Penegakan Hak Asasi Manusia", J urnal IImu Hukum Kanun, Vol. 24 No. 9, Tahun 1999, Banda Aceh: Fakultas Hukum Universitas Syiah Kuala, hlm. 524.
Pemaparan substansi UUD 1945 memberikan implikasi atas peran pers dalam konteks demokrasi. Pers diartikan sebagai bagian (subsistem) dari sistem yang lebih besar, yaitu sistem komunikasi. Sistem komunikasi dapat dilihat sebagai bagian atau sub sistem dari sistem yang lebih besar (yaitu sistem masyarakat) yang dilayaninya. Suatu sistem komunikasi sebenarnya terkandung (inherent) dalam setiap sistem masyarakat. Corak dari sistem komunikasi di dalam suatu masyarakat tidak dapat ditentukan oleh corak, bentuk dan keragaman masyarakat itu sendiri.

Pada umumnya orang melihat sistem pers itu dikaitkan dengan bentuk sistem sosialnya, dan selalu dihubungkan dengan sistem pemerintahan yang ada atau bentuk negara dimana sistem pers itu berada. F. Rachmadi berpendapat:

Sistem pers memang tidak terlepas hubungannya dengan sistem sosial dan sistem politik dari suatu masyarakat atau bangsa, karena hubungan pers itu adalah dengan pemerintah dan masyarakat, di mana hubungannya atau interaksinya itu tidak bisa dihilangkan. Jadi sistem pers itu tidak akan terlepas dari pengaruh pemikiran atau filsafat yang mendasari sistem masyarakat dan sistem pemerintahan, dimana pers itu berada dan beroperasi. $^{8}$

Berdasarkan uraian di atas, maka tulisan ini di maksudkan untuk menganalisis kebebasan pers di Indonesia pada masa Orde Baru dan Era Reformasi menurut ketentuan peraturan perundang-undangan yang berlaku.

\section{Pembahasan \\ Pengertian Pers}

Pengertian pers dibatasi pada pengertian sempit dan pengertian luas, seperti dikemukakan oleh Oemar Seno Adji, Pers dalam arti sempit seperti diketahui mengandung penyiaran-penyiaran pikiran, gagasan ataupun berita-berita dengan jalan kata tertulis. Sebaliknya, pers dalam arti yang luas memasukkan di dalamnya semua media mass communi-

8 F. Rachmadi, 1990, Perbandingan Sistem Pers, Jakarta: Gramedia, hlm. 14. 
cations yang memancarkan fikiran dan perasaan seseorang baik dengan kata-kata tertulis mau pun dengan kata-kata lisan. Ditegaskan oleh Commission on The Freedom of The Press, bahwa: "If will be understood that we ae using the term "press" to include all means of communicating to the public newspapers, magazines, or books, by radio broadcast, by television, or by films". ${ }^{9}$

Pers mempunyai dua sisi kedudukan, yaitu pertama merupakan medium komunikasi yang tertua di dunia, dan kedua pers sebagai lembaga masyarakat dan juga sistem politik. Sebagai medium komunikasi, pers harus sanggup hidup bersama-sama dan berdampingan dengan lembaga-lembaga lainnya dalam suatu keserasian. Dalam hal ini, sifat hubungan antara satu sama lainnya tidak akan luput dari landasan falsafah dan ideologi yang dianut oleh masyarakatnya dan juga struktur/sistem politik yang berlaku.

Pengertian pers menurut Undang-undang No. 11 Tahun 1966 tentang Ketentuan-ketentuan Pokok Pers Pasal 1 ayat (1) adalah sebagai berikut:

Pers adalah lembaga kemasyarakatan alat revolusi yang mempunyai karya sebagai salah satu media komunikasi massa yang bersifat umum berupa penerbitan yang teratur waktu terbitnya diperlengkapi atau tidak diperlengkapi dengan alat-alat teknik lainya.

Adapun pengertian pers menurut Pasal 1 ayat (1) Undang-undang No. 40 Tahun 1999 tentang pers:

Pers adalah lembaga sosial dan wahana komunikasi massa yang melaksanakan kegiatan jurnalistik meliputi mencari, memperoleh, memiliki, menyimpan, mengolah dan menyampaikan informasi baik dalam bentuk tulisan, suara, gambar, serta data dan grafik maupun dalam bentuk lainnya dengan menggunakan media cetak, media elektronik dan segala jenis saluran yang tersedia.

\footnotetext{
Mahdor Syatri, "Kebebasan Pers: Demokrasi vs ReguIasi", Majalah Sriwijaya, Vol. 38 No. 2, Tahun 2004, Palembang: Pusat Penelitian Universitas Sriwijaya, hlm. 35.
}

\section{Sistem Pers dan Kebebasan Pers}

Menurut W.J.S. Poerwadaminta sistem adalah sekelompok bagian (alat dan sebagainya) yang bekerja bersama-sama untuk melakukan sesuatu maksud. Apabila salah satu bagian rusak atau tidak dapat menjalankan tugasnya, maka maksud yang hendak dicapai tidak akan terpenuhi, atau setidak-tidaknya sistem yang telah terwujud akan mendapat gangguan. ${ }^{10}$

Ciri sistem adalah berorientasi pada tuj uan dengan perilakunya atau segala kegiatannya bertujuan. Secara umum tujuan sistem adalah menciptakan atau mencapai sesuatu yang berharga, sesuatu yang mempunyai nilai (value). Pada umumnya orang melihat suatu sistem (pers) itu dikaitkan dengan bentuk sosialnya, dan selalu dihubungkan dengan sistem pemerintahan yang ada atau bentuk negara dimana sistem pers berada dan beroperasi. Setelah Perang Dunia II berakhir dan kemudian memasuki perang dingin antara Barat dan Timur, Fred S. Siebert, Theodore Peterson dan Wilbur Schramm tampil dengan empat macam teori persnya untuk menjelaskan perkembangan kondisi di dunia. Keempat teori pers yang dikemukakan oleh Fred S. Siebert dan kawankawan itu (The four theories of the press, Empat Teori Pers), terdiri dari: ${ }^{11}$

\section{Teori Pers Otoritarian}

Kehidupan pers yang pertama muncul adalah teori otoritarian karena erat kaitannya dengan pandangan filosofis tentang hakikat negara dan masyarakat. Menurut teori ini, negara dianggap sebagai ekspresi tertinggi dari organisasi kelompok manusia, mengungguli masyarakat dan individu. Negara merupakan hal terpenting dalam pengembangan manusia seutuhnya. Di dalam dan melalui negara manusia mencapai tujuannya sehingga tanpa negara manusia tetap menjadi manusia primitif. Hubungan antara pers dan negara pada saat teori ini lahir ada dalam kerangka yang demikian itu.

10 W.J.S. Poerwadaminta, 1976, Kamus Umum Bahasa Indonesia, J akarta: Balai Pustaka, hlm. 1955.

11 Krisna Harahap, 2003, Pasang Surut Kemerdekaan Pers di Indonesia, Bandung: PT. Grafitri, hlm. 1-7. 
Prinsip-prinsip utama teori ini adalah media selamanya (akhirnya) harus tunduk pada penguasa yang ada; penyensoran dapat dibenarkan; kecaman tidak dapat diterima terhadap penguasa atau penyimpangan dari kebijaksanaan resmi; dan wartawan tidak mempunyai kebebasan di dalam organisasinya.

\section{Teori Pers Libertarian}

Kalau pada teori pers otoriter tekanan diberikan kepada negara maka dalam teori pers liberal beralih kepada individu dan masyarakat yang kemudian melahirkan pemikiran-pemikiran tentang demokrasi. Dalam pemikiran yang demikian itu, fungsi utama masyarakat adalah untuk memajukan kepentingan anggotanya sehingga faham ini membagikan posisi negara sebagai ekspresi manusia yang tertinggi.

Ciri-ciri pers yang merdeka berdasarkan teori libertarian dapat diperinci sebagai berikut. Pertama, publikasi bebas dari setiap penyensoran pendahuluan; kedua, penerbitan dan pendistribusian terbuka bagi setiap orang tanpa memerlukan izin atau lisensi; ketiga, kecaman terhadap pemerintah, pejabat atau partai politik tidak dapat dipidana; keempat, tidak ada kewajiban mempublikasikan segala hal; kelima, publikasi "kesalahan" dilindungi sama halnya dengan publikasi kebenaran dalam hal-hal yang berkaitan dengan opini dan keyakinan; keenam, tidak ada batasan hukum terhadap upaya pengumpulan informasi untuk kepentingan publikasi; dan ketujuh, wartawan punya otonomi profesional dalam organisasi mereka.

\section{Teori Pers Tanggungjawab Sosial}

Teori tanggung jawab sosial berdasarkan pandangannya kepada suatu prinsip bahwa kemerdekaan pers mempunyai kewajiban untuk bertanggung jawab kepada masyarakat guna melaksanakan tugas-tugas pokok yang dibebankan kepada komunikasi massa dalam masyarakat modern dewasa ini. Di sini prinsip kemerdekaan itu masih dipertahankan dengan penambahan tugas dan beban bahwa kemerdekaan yang dimiliki haruslah disertai kewajiban-kewajiban sebagai tanggung jawab.
Prinsip utama teori pers tanggung jawab sosial dapat ditandai sebagai berikut: media mempuyai kewajiban tertentu kepada masyarakat; kewajiban tersebut dipenuhi dengan menetapkan standar yang tinggi atau profesional tentang keinformasian, kebenaran, obyektivitas, keseimbangan dan sebagainya; dalam menerima dan menerapkan kewajiban tersebut, media seyogyanya dapat mengatur diri sendiri di dalam kerangka hukum dan lembaga yang ada; dan media seyogyanya menghindarkan segala sesuatu yang mungkin menimbulkan kejahatan yang mengakibatkan ketidaktertiban umum atau juga penghinaan terhadap minoritas etnik atau agama.

\section{Teori Pers Komunis (Marxist, Totaliter)}

Teori ini bertolak pangkal dari ajaran Karl Marx tentang perubahan sosial. Menurut teori komunis, pers sepenuhnya merupakan alat negara. Konsekuensinya, pers harus tunduk kepada pemerintah. Pers tidak lebih alat dari Partai Komunis yang berkuasa, media harus melakukan apa yang terbaik bagi partai dan pemerintah. Ciri-ciri teori ini dapat dirinci sebagai berikut: media berada di bawah pengendalian kelas pekerja, karena itu melayani kepentingan kelas tersebut; media tidak dimiliki secara pribadi; masyarakat berhak melakukan sensor dan tindakan hukum setelah terjadinya peristiwa, publikasi anti masyarakat.

\section{Sistem Pers dan Kebebasan di Masa Orde Baru}

Konsep kemerdekaan pers di sini adalah sebagai terjemahan dari the freedom of the press, yang secara sederhana dapat dianalogikan dengan arti free from the dom, atau bebas dari penguasa. Dalam perspektif sejarah, pengakuan dan perlindungan hak untuk merdeka dari pengaruh atau tekanan penguasa sudah di mulai sejak deklarasi Magna Charta (1215). Khusus dalam bidang pers, secara eksplisit ditetapkan di dalam Pasal 12 Virginia Bill of Right (15 Mei 1776) tentang kemerdekaan persuratkabaran. Piagam Virginia ini kemudian di masukkan ke dalam Konstitusi Amerika Serikat (1787). Pada tahun 1789, Piagam Virginia itu di adopsi pula oleh Prancis menjadi Declaration 
de droits de I'homme et du citoyen, atau Naskah Pernyataan Hak Asasi Manusia dan Warganegara.

Di Indonesia masalah kemerdekaan/ kebebasan pers adalah apakah sudah sesuai dengan konstitusi serta undang-undang yang berkaitan dengan fungsi dan peranan pers dalam kehidupan demokrasi. Hal ini sangat penting dirumuskan, mengingat pengalaman selama ini, hampir setiap sistem politik menyebut dirinya demokratis dan menjamin adanya kebebasan pers, tetapi dalam praktiknya otoriter dan membelenggu pers. ${ }^{12}$ Pada rezim Orde Lama, misalnya dengan kembalinya Indonesia memakai Undang-undang Dasar 1945 dan menggunakan sistem politik pemerintahan presidensil pada tahun 1959 sampai 1966 yang terjadi kemudian adalah sebaliknya. Demokrasi yang seharusnya tanpa embel-embel, diubah menjadi terpimpin atau dipimpin oleh seseorang, sedangkan kemerdekaan pers yang seharusnya dijamin oleh Undang-undang Dasar 1945, justru dikebiri.

Begitu juga halnya dengan Orde Baru, pada mulanya memang mengiming-iming terjaminnya kemerdekaan pers dengan dikeluarkannya Undang-undang Pokok Pers Nomor 11 Tahun 1966. Undang-undang ini sebetulnya hanya semacam cek kosong yang kalau dipraktikkan tidak sesuai dengan yang tertulis. Dalam konsideran undang-undang ini disebutkan bahwa pers harus mencerminkan kehidupan demokrasi, karena itu, berbagai ketentuan yang berkaitan dengan ketentuan pers, misalnya, Penpres Nomor 6 Tahun 1963 tentang pembinaan pers dicabut.

Sepintas, Undang-undang No. 11 Tahun 1966 ini memberikan kemerdekaan pers, tetapi jika ditelusuri lagi pasal-pasalnya, ternyata di balik itu terdapat berbagai belenggu bagi kehidupan pers di Indonesia. Coba lihat, misalnya dalam Pasal 4 Undang-undang No. 11 Tahun 1966, disebutkan "Terhadap pers nasional tidak dikenakan sensor dan pembredelan". Celaka-

12 J ohanes Usfunan, "Jaminan dan perlindungan kebebasan Pers di Indonesia", Majalah ilmiah Kertha Wicaksana, Vol. 5 No. 9, Tahun 1999, Denpasar: Fakultas Hukum Universitas Warmadewa, hlm. 6 nya, pada pasal berikutya yaitu Pasal 20 ayat 1 Undang-undang No. 11 Tahun 1966 dikatakan "Untuk menerbitkan pers diperlukan Surat Izin Terbit. ${ }^{13}$

Undang-undang No. 11 Tahun 1966 ini kemudian diganti dengan Undang-undang No. 21 Tahun 1982 tentang SIUPP, tetapi yang terjadi secara substansial tidak ada perubahan. Kontrol pemerintah terhadap pers melalui keharusan mendapatkan surat izin terbit makin kuat. Bagi yang tidak punya izin, tidak boleh menerbitkan pers. Selain terjadi pembatasanpembatasan yang dikaitkan dengan kepentingan pemerintah juga cenderung melahirkan praktik korupsi, karena permintaan terhadap surat izin begitu banyak, tetapi mendapatkannya begitu sulit.

Demikianlah realitas pers Indonesia di masa Orde Baru. Kemerdekaan pers secara sistematis dikebiri melalui Undang-undang Pokok Pers Nomor 11 Tahun 1966 kemudian diganti dengan Undang-undang Pokok Pers Nomor 21 Tahun 1980. Pengebirian itu dilakukan dalam bentuk pemberlakuan SIUPP; pembredelan pers melalui pencabutan SIUPP; pembatasan fungsi pers melalui pemanggilan-pemanggilan wartawan dan pemimpin redaksi oleh penguasa; dan melalui teror telepon bahkan ancaman fisik dan pembunuhan. ${ }^{14}$

J elas sekali bahwa kemerdekaan pers tidak hanya dipasung melalui pembatasan-pembatasan melalui kegiatan jurnalistiknya seperti pembredelan, budaya telepon, ancaman, bahkan pembunuhan terhadap wartawan yang dinilai menganggui kepentingan orang yang dekat dengan kekuasaan. ${ }^{15}$ Pada acara-acara briefing terhadap para pemimpin redaksi, tak jarang pula dipesankan agar tidak memuat berita kegiatan mahasiswa di halaman depan. Gejala ini terus berlangsung hingga menjelang kejatuhan

13 Istilah Surat Izin Terbit diganti melalui Undang-undang Pokok Pers Nomor 21 Tahun 1982 tentang Surat Izin Usaha Penerbitan Pers. Ketentuan ini sebetulnya, sama dengan produk hukum represif dalam Peperti Nomor 10 Tahun 1960 di era Demokrasi Terpimpin.

14 Krisna Harahap, op. cit., hlm. 53.

15 Sebagai contoh adalah kasus Fuad Muhammad Syafrudin atau biasa dipanggil Udin, wartawan harian Bernas, Yogyakarta, adalah salah seorang korban pembunuhan di era Orde Baru. Hingga kini kasus Udin hilang bagai ditelan bumi tak tahu ujung pangkalnya lagi. 
Orde Baru. Bersamaan dengan penekanan terhadap kemerdekaan pers, hal yang sama juga dilakukan terhadap para mahasiswa, misalnya dengan dilakukannya penculikan dan penembakan mahasiswa Universitas Trisakti di Jakarta, pada aksi menuntut Soeharto mundur dari jabatan Presiden (Mei 1998). Bahkan, dalam kurun waktu yang hampir bersamaan, beberapa penerbit anti pemerintah, seperti Tabloid Delik, Majalah Berita Tempo, dan Editor dicabut SIUPP nya oleh pemerintah pada tahun 1996. Majalah SINAR, yang waktu itu penulis pimpin sebagai pemimpin redaksi, mendapat peringatan keras terakhir dari Deppen, karena memuat berita penyerangan kantor DPP PDIP di Jalan Diponegoro Jakarta, serta memuat foto uskup Belo di sampul depan setelah ia mendapat hadiah Nobel Perdamaian. Pencabutan SIUPP Majalah Tempo, berkaitan dengan pembongkaran kasus dugaan korupsi yang dilakukan mantan Wakil Presiden BJ Habibie yang diduga melakukan manipulasi pembelian kapal perang bekas Jerman Timur, sedangkan Tabloid Delik dan Majalah Editor dinilai tidak loyal terhadap pemerintah, dan selalu memberitakan kegiatan mahasiswa dengan porsi yang besar. Oleh karena itu, SIUPP ketiga penerbitan itu dicabut oleh Deppen tanpa melalui proses pembuktian dan hukum yang adil dan benar. Pencabutan itu, pasti menggunakan dasar hukum Permenpen Nomor 1 Tahun 1984 setelah mendengar Dewan Pers. Dengan kata lain, selain Menteri Penerangan, Dewan Pers ikut bertanggung jawab terhadap pembredelan tanpa melalui proses peradilan.

Melalui uraian di atas terlihat dengan jelas keterkaitan antara pemasungan, sensor dan pembredelan pers dengan konfigurasi politik yang otoriter, serta semakin maraknya praktik buruk birokrasi, korupsi, kolusi dan nepotisme. Rezim otoriter dan korup itu berjalan tanpa kontrol sama sekali dan menyebabkan lahirnya rezim yang tampak kokoh dari luar, akan tetapi di dalamnya rapuh.

Realitas demikian pada akhirnya membuat ekonomi bangsa Indonesia bertambah terpuruk. Lebih-lebih akibat krisis moneter yang diawali dengan depresiasi nilai rupiah terhadap dolar Amerika Serikat, banyaknya utang luar negeri yang dipakai untuk proyek fiktif, tingginya inflasi, dan munculnya pemutusan hubungan kerja, serta pengangguran besar-besaran. Hal ini mengakibatkan kian tingginya tingkat penolakan rakyat terhadap rezim Orde Baru di bawah kepemimpinan J enderal Soeharto. ${ }^{16}$

Kehidupan pers seperti di atas kemudian berdampak terhadap corak isi penerbitan di Indonesia yang cenderung menjadi instrumen bisnis para pemilik modal dengan melupakan fungsi kontrol sosialnya. Di satu sisi, terkesan terjadi perubahan yang signifikan dalam perkembangan pers di Indonesia, dengan ditandai banyaknya jumlah surat kabar, majalah dan televisi swasta. Akan tetapi, di sisi lain, gejala ini diiringi pula dengan menguatnya rezim otoriter yang tak terjamah oleh kritik dan kontrol pers. Berdasarkan fenomena pers yang demikian, mana mungkin pers dapat melakukan fungsi kontrol karena hak hidupnya sangat tergantung pada SIUPP yang dikuasai pemerintah.

Selain itu, sistem politik Orde Baru yang otoriter dan korup itu, ternyata tak sekuat yang tampak di permukaan. Hal ini, antara lain, di sebabkan kekuasaan yang dimilikinya tidak sepenuhnya didukung oleh entitas demokrasi, antara lain oleh pers yang bebas menyampaikan kritik dan kontrol. ${ }^{17}$ Seperti dikatakan, kehadiran kemerdekaan pers sebenarnya dapat memperkokoh masyarakat dan penguasa sehingga terhindar dari kebobrokan yang pada gilirannya menyebabkan kejatuhannya. Faktanya, faktor utama yang menyebabkan tumbangnya Orde Baru adalah terlalu banyaknya kebobrokan pemerintah, seperti banyaknya hutang luar negeri Indonesia, tingginya tingkat korupsi, macetnya peran lembaga demokrasi, seperti legislatif, termasuk dibelenggunya kemerdekaan pers.

Tesis yang mengatakan bahwa gerakan mahasiswa berkaitan erat dengan pemberitaan mass media, tidak sepenuhnya benar. Hal ini disebabkan, setelah pemerintah mengeluarkan berbagai produk hukum represif yang mem-

16 B. Hestu Cipto Handoyo, op. cit., hlm. 240.

17 D.N Susilastuti, "Kebebasan Pers Pasca Orde Baru", J urnal IImu Sosial Dan IImu Politik (J SP), Vol. 4 No. 2, Tahun 2000, Yogyakarta: Fakultas IImu Sosial dan IImu Politik Universitas Gadj ah Mada, hlm. 228. 
belenggu kemerdekaan pers, terbukti tidak mampu membendung aksi-aksi mahasiswa melawan Orde Baru, yang pada akhirnya mengakibatkan kekuasaan Soeharto tumbang (21 Mei 1998). Kejatuhan konfigurasi politik Orde Baru kemudian melahirkan suatu rezim baru yang dikenal dengan konfigurasi politik reformasi.

Pengukuhan teori otoriter dilakukan meIalui peraturan perundang-undangan oleh pemerintah, pembredelan dan sebagainya. Oleh karena keberadaan pers sepenuhya dimaksudkan untuk menunjang pemerintah yang bersifat otoriter itu, maka pemerintah langsung menguasai dan mengawasi kegiatan media massa. Akibatnya, sistem pers yang berlaku sepenuhnya dikendalikan oleh pemerintah. Di sini pers berfungsi dari atas ke bawah (top down). Penguasalah yang menentukan apa yang akan diterbitkan, sebab kebenaran merupakan monopoli mereka yang berkuasa. Dalam keadaan yang demikian fungsi pers sekedar menyampaikan apa yang diinginkan oleh penguasa untuk diketahui oleh rakyat. Kalaupun ada kebebasan yang dapat dinikmati oleh pers, maka hal tersebut tergantung kepada kemurahan hati penguasa yang memiliki kekuasaan mutlak.

Prinsip-prinsip utama teori ini adalah media selamanya (akhirnya) harus tunduk pada penguasa yang ada; penyensoran dapat dibenarkan; kecaman tidak dapat diterima terhadap penguasa atau penyimpangan dari kebijaksanaan resmi; dan wartawan tidak mempunyai kebebasan di dalam organisasinya. ${ }^{18}$ Dengan demikian, sistem pers dan kebebasan pers pada masa Orde Baru sangat condong otoriter, sesuai dengan Teori Pers Otoritarian dari Fred S. Siebert.

\section{Sistem Pers dan Kebebasan di Era Reformasi}

Berakhirnya pemerintahan Presiden Soeharto pada tanggal 21 Mei 1998 telah membawa bangsa Indonesia kepada pusaran tuntutan perubahan yang fundamental dalam segenap bidang kehidupan berbangsa dan bernegara. Tuntutan reformasi hukum merupakan salah satu yang berembus demikian kuat sejak Mei

18 Krisna Harahap, op.cit., hal. 3.
1998. Begitu pula halnya dalam bidang politik hukum termasuk dalam bidang kemerdekaan pers.

DPR yang menyetujui pencabutan UU Nomor 21 tahu 1982 melalui UU Nomor 40 Tahun 1999 merupakan produk hukum yang dibuat legislatif hasil pemilu yang dinilai sangat demokratis. ${ }^{19}$ Dalam konteks UU Nomor 40 Tahun 1999, hukum merupakan variabel berpengaruh, kemudian konfigurasi politik sebagai variabel terpengaruh.

Produk hukum pada era reformasi tentang pers ini dapat dikatakan sebagai sapu jagatnya kemerdekaan pers Indonesia, setelah sekitar dua puluh delapan tahun didera pembelengguan oleh rezim Orde Baru. Dikatakan sebagai sapu jagat karena undang-undang ini menghapus semua ketentuan represif yang pernah berlaku pada era Orde Baru, seperti: Pasal 9 ayat 2 UU No. 40 Tahun 1999 meniadakan keharusan mengajukan SIUPP untuk menerbitkan pers; Pasal 4 ayat 2 UU Nomor 40 tahun 1999 menghilangkan ketentuan sensor dan pembredelan pers; dan Pasal 4 ayat 2 juncto Pasal 18 ayat 1 UU Nomor 40 Tahun 1999: melindungi praktisi pers dengan mengancam hukum pidana dua tahun penjara atau denda Rp. 500.000 juta bagi yang menghambat kemerdekaan pers.

Selain menghapus berbagai kendala kemerdekaan pers tersebut di atas, UU Nomor 40 Tahun 1999 juga memuat isi pokok sebagai berikut. Pertama, Pasal 2 UU Nomor 40 Tahun 1999: kemerdekaan pers adalah perwujudan dari kedaulatan rakyat yang berasaskan prinsipprinsip demokrasi, keadilan dan supremasi hukum; dan kedua, Pasal 4 ayat 1 UU Nomor 40 Tahun 1999: Kemerdekaan pers adalah hak asasi warga negara yang hakiki dan dalam rangka menegakkan keadilan dan kebenaran, serta memajukan dan mencerdaskan bangsa.

\footnotetext{
19 Pemilu 1999 dinilai demokratis karena setiap pemilih dapat melaksanakan asas pemilu bebas, umum dan rahasia, serta dipantau oleh banyak Lembaga Swadaya Masyarakat lokal dan internasional yang independen, termasuk juga dipantau oleh Presiden AS, J immy Cater, Pemilu 1999, juga dilakukan transparan oleh lembaga independen yang dipilih melalui proses demoratis.
} 
Pembebasan kegiatan pers dari belenggu rezim Orde Baru di era reformasi, ada tali temalinya dengan realitas produk hukum represif dan konfigurasi politik otoriter yang dirasakan sangat pahit selama tiga puluh dua tahun Orde Baru. Berbagai penyempurnaan, penghapusan dan pembuatan nilai-nilai baru yang relevan dengan nilai-nilai demokrasi dan hukum responsif merupakan antitetis dari keadaan sebelumnya yang membelenggu pers Indonesia.

Gejala ini mirip dengan kejadian awal kejatuhan Orde Lama yang diikuti lahirnya produk hukum responsif pada pasca Orde Lama dalam bidang pers, misalnya melalui Tap MPRS Nomor XXXII/1966 dan UU Nomor 11 Tahun 1966 tentang Ketentuan-ketentuan Pokok Pers TAP MPRS Nomor XXXII/ 1966 itu menegaskan, kemerdekaan berdasarkan amanah Pasal 28 Undang-undang Dasar 1945 mutlak segera di wujudkan.

Demikian pula halnya gejala pada awal Reformasi, Pasal 28 UUD 1945 yang sudah di injak-injak oleh rezim sebelumnya, kembali masuk dalam perumusan produk hukum responsif dalam bidang pers, yaitu UU Nomor 40 Tahun 1999. UU Nomor 40 tahun 1999, telah menghidupkan kembali isi Pasal 28 UUD 1945 tentang pentingya kemerdekaan pers yang terkubur melalui Tap MPR Nomor IV/ 1978 dan UU Nomor 21 tahun 1982 pada era Orde Baru.

Pencabutan yuridis yang membelenggu kemerdekaan pers Orde Baru itu ternyata menimbulkan euforia atau pesta pora kemerdekaan pers. Hal itu terjadi karena setiap orang bebas mendirikan penerbitan, tanpa keharusan memiliki SIUPP, serta dijamin tidak ada sensor dan pembredelan. Dampaknya, penerbitan pers tumbuh bagai jamur di musim hujan. Hal ini memungkinkan bagi setiap warga masyarakat profesional maupun amatir dapat mendirikan penerbitan pers.

Berdasarkan data yang dihimpun Serikat Penerbit Surat Kabar (SPS), pada era Reformasi terjadi kenaikan jumlah penerbitan yang sangat signifikan setelah keran kemerdekaan pers dibuka tahun 1999. Pada tahun 1997, jumlah me-ia cetak di Indonesia memiliki 289 pener- bitan, kemudian pada tahun 1999 jumlah penerbitan melonjak drastis menjadi 1687.

Menteri Komunikasi dan Informasi, Syamsul Muarif sering mengatakan bahwa pada era reformasi ini kemerdekaan pers dan kedudukan pers sangat kuat. Hal itu digambarkan, betapa pemerintah sangat berhati-hati dalam menanggapi berita dan kritik tentang pers dalam hal Daerah Operasi Militer di Ambon. Begitu kuatnya pengaruh dan kedudukan pers di era Reformasi, sehingga kedudukan pers Indonesia bukan lagi sebagai pilar keempat demokrasi, tetapi menjadi pilar pertama demokrasi. Jadi gejala pers di Indonesia, bukan lagi sebagai pilar keempat demokrasi seperti yang dijuluki dalam teori the four estate of democracy life. Gejala kemerdekaan pers di Indonesia, tercermin pula melalui hasil survey organisasi Reporter Without Border, di Paris tahun 2002, bahwa kemerdekaan pers di Indonesia terbaik di Asia Tenggara.

Kebebasan ini bukanlah tanpa kekhawatiran, terutama tampak dengan adanya kritikan-kritikan dari pihak pemerintah dan kelompok masyarakat tertentu. ${ }^{20}$ Kritikan itu sangat variatif, ada yang menyoroti kelemahan-kelemahan dalam proses pemberitaan yang di anggap kurang balance antara kepentingan masyarakat dan kepentingan (tingkat oplah) pers. Pihak pers dinilai cenderung mengutamakan konsep berita yang kurang objektif, sensasional dan sangat partisipan; kemudian pada level etis kemanusiaan kebebasan pers itu dinilai telah mengangkangi nilai dan norma moral kemasyarakatan dan telah meruntuhkan kaidah jurnalistik itu sendiri. Kenyataannya, dalam rapat dengar pendapat yang dihadiri oleh perwakilan kalangan pers, antara lain : Aliansi J urnalis Independen (AJ I), PWI dan MPPI dengan anggota Panitia Ad Hoc I BP MPR masih menunjukkan keragu-raguan dan kecemasan terhadap kebebasan pers. Mereka mengkhawatirkan kebebasan pers akan menjadi sebebas-

20 Lihat dan bandingkan dengan Joko Tutuko dan Abdul Latif, "Reformasi Dan Kebebasan Pers: Respon Insan Pers Terhadap UU No. 40 Tahun 1999 Tentang Pers", J urnal Publica, Vol. 4 No. 1, Tahun 2008, Malang: Fakultas IImu Sosial dan IImu Politik Universitas Muhammadiyah, hlm. 27-31. 
bebasnya, sehingga mereka menyatakan bahwa kebebasan pers itu perlu diatur. Reaksi ini merupakan rejuvenansi konsep pengekangan pers oleh pemerintah pra transisi. Kekhawatiran tersebut senada dengan kecurigaan pemerintah bahwa kebebasan pers yang tanpa kontrol telah melahirkan satu model kebebasan pers yang saat ini sudah berlebihan dan menjadi sumber kekuasan baru. Kekhawatiran masyarakat terhadap kebebasan pers, juga muncul dalam bentuk aksi perlawanan dari masyarakat dalam bentuk kekerasan pers. Hal ini antara lain di tandai dengan penyerangan terhadap harian J awa Post di Surabaya oleh Banser (Barisan Serba Guna) Anshor yang merupakan pendukung Presiden Abdurrahman Wahid.

Catatan AJ I dalam laporan tahunan periode 2004 menyebutkan, terdapat 32 kasus gugatan terhadap media dan jurnalis, yang meliputi: pertama, kasus Redaktur Harian Rakyat Mereka, Supratman yang mempublikasikan isi berita berupa penghinaan terhadap Presiden. la di nyatakan bersalah dan divonis dengan 6 bulan penjara dengan masa percobaan 12 bulan. la di nyatakan terbukti melakukan penghinaan dengan sengaja terhadap presiden yang diatur dalam pasal 134 jo Pasal 65 ayat (1) KUHP. Kemudian majalah Tempo dua tahun terakhir ini harus bolak-balik ke pengadilan guna melayani kasus yang dibawa ke meja hijau oleh pengusaha Tomy Winata. Ada sejumlah kasus yang diajukan Tomy Winata baik ke Pengadilan Negeri J akarta Pusat maupun dan Pengadilan Negeri J akarta Selatan. Salah satu dari beberapa kasus tersebut diputuskan oleh Pengadilan Negeri Jakarta Pusat yang memutuskan Tempo bersalah dalam kasus pencemaran nama baik, akibat pemberitaan di majalah Tempo edisi 3-9 Maret 2003 yang berjudul "Ada Tomy di Tenabang". Pengadilan Negeri Jakarta Pusat meminta Tempo untuk meminta maaf setengah halaman di Koran Tempo, Media Indonesia dan Warta Kota, dan setengah halaman di majalah Tempo selama tiga kali berturut, untuk memulihkan nama baik Tomy Winata. Sementara dalam kasus yang lainnya lagi antara Koran Tempo vs Tomy Winata, Koran Tempo divonis oleh Majelis Hakim Pengadilan Negeri J akarta
Selatan untuk membayar uang sebesar 1 juta dollar, karena sebuah tulisan di koran Tempo edisi 6 Februari berjudul "Guberur Ali Mazi Bantah Tomy Winata Buka Usaha J udi". Tulisan ini dinilai menciptakan opini bahwa Tomy adalah musuh masyarakat.

Setelah kebebasan pers Indonesia mulai menggelinding, banyak orang yang mengkhawatirkan bahwa pemberitaan pers yang sensasional akan berakibat bagi pemunduran bangsa. Proses pembodohan akan terkristalisasi meIalui dunia pers. Berawal dari sinilah muncul berbagai ancaman terhadap pers, seperti isu SARA, tekanan massa, bahkan legal resentment (ancaman gugatan), business interest (kepentingan bisnis), suap dan sebagainya. Satu hal yang kini menonjol sebagai ancaman adalah kekecewaan terhadap pers bebas, yang jika dicermati bisa menjadi satu opini publik luas di masyarakat, yang disebut pers kebablasan. $\mathrm{Na}$ mun, lebih baik pers kebablasan daripada tidak bebas sama sekali. Tesis ini mencoba menelisik pergeseran paradigma "mekanistik" ke paradigma "holistik" tentang kebebasan pers. Fenomena kebebasan pers ini harus dilihat dalam keseluruhannya, dalam arti kebebasan pers dilihat dalam kaitannya dengan nilai-nilai kultur, sosial, politik dan ekonomi semua persoalan dalam negara yang kita alami sekarang adalah suatu harapan yang berlebihan.

Suatu studi komparatif di beberapa negara demokrasi menunjukkan adanya persesuaian antara demokrasi dan kebebasan. Demokrasi mengimplikasikan adanya kebeba-san sipil dan politik, yaitu kebebasan untuk berbicara, menerbitkan, berkumpul dan berorganisasi. Garis persinggungan antara demokrasi dan kebebasan pers merupakan rantai kehidupan manusia dalam dimensi politisnya yang saling interdependentif antara nilai-nilai dan kepentingan. ${ }^{21}$

Pada praksisnya, kebebasan pers berputar pada perdebatan dan kontroversi antara pola kepentingan dua arah; kepentingan pemerintah

21 Lihat dan Bandingkan dengan Abdul Muis, "Perlindungan Hukum Terhadap Kebebasan Pers Pada Masa Orde Baru Dan Era Awal Reformasi", Jurnal IImu Hukum Kanun, Vol. 10 No. 26, Tahun 2000, Banda Aceh: Fakultas Hukum Universitas Syiah Kuala, hlm. 774-788. 
untuk menjaga rahasia politik, keutuhan dan kedaulatan negara, dokumen rahasia dan pola kebijakan terhadap publik, dengan kepentingan masyarakat yang menutut partisipasi aktif dalam menyalurkan aspirasi politik mereka, dan untuk memperoleh informasi tanpa melanggar keutuhan hak kebebasan pribadi setiap individu. Sejatinya, kebebasan pers dalam menyebarluaskan informasi kepada masyarakat tanpa adanya pembatasan baik dalam bentuk regulasi maupun dengan tindakan kekerasan. Pers nasional bebas mempunyai hak untuk mencari, memperoleh dan menyebarluaskan tanpa gangguan maupun swasensor baik dari pemilik media itu sendiri maupun dari pihak pemerintah dalam bentuk regulasi.

Regulasi dalam bentuk UU tentang pers yang membatasi ruang gerak pers memang tidak ada, namun yang dirisaukan oleh insan pers adalah terjadinya kriminalisasi yang menjadi ancaman terhadap kebebasan pers, padahal seharusnya kalaupun terdapat pemberitaan yang keliru, dapat mengikuti mekaisme yang diatur dalam UU Pers, seperti hak jawab dan hak koreksi; bukan dengan cara memenjarakan wartawan, itu yang menjadi suatu kekeliruan Kasus kriminalisasi terhadap pers dapat dilihat pada Kasus Tempo, Rakyat Merdeka, Radar Yogya, kemudian kasus Suara Indonesia Baru (SIB) Medan, yang menurunkan serial investigasi tentang judi illegal yang dibekingi oleh pejabat Sumatera Utara. Kemudian sekelompok anak muda yang dipolitisir masuk dan mengobrakabrik SIB. Kasus-kasus kriminalisasi terhadap pers merupakan masalah yang sangat dirisaukan oleh kalangan jurnalis dan media.

Pers sebagai salah satu pilar demokrasi mempunyai fungsi kontrol dan melakukan pengawasan terhadap hal-hal yang berkaitan dengan kepentingan publik. Dalam UU pers di jelaskan bahwa media mempunyai peranan untuk melakukan kontrol sosial, pengawasan untuk mencegah terjadinya penyelewengan dan penyalahgunaan. ${ }^{22}$

22 Daud Aidir Amin, "Membangun Optimalisasi Kebebasan Pers di Tengah Konservatisme Penegakan Hukum", J urnal IImiah Pusat Pengkajian dan Pengembangan Kebi-
Kini kebebasan pers sedang mengalami kemajuan. Kalau pada era Orde Baru terdapat ketentuan tentang pembredelan yang jelasjelas diatur dalam UU yang lama, yang menyebabkan pemerintah dapat menghentikan produksi media yang berseberangan dengan pemerintah, namun ketentuan itu tidak ada lagi daIam UU No. 40 Tahun 1999. Meskipun demikian, UU yang baru ini tidak menjamin adanya perubahan di tingkat pelaksanaan. Masih saja terjadi kriminalisasi terhadap pers.

Adanya pergantian aktor dalam memusuhi pers yang tadinya negara, kemudian diganti oleh kroni-kroni negara yang berusaha membatasi, mulai dari pengusaha, pejabat negara, kemudian tokoh-tokoh masyarakat yang bisa membayar advokat dengan harga tinggi.

Menurut teori pers liberal, pers bukan instrumen pemerintah, akan tetapi sarana hati masyarakat untuk mengawasi pemerintah dan menentukan sikap terhadap kebijaksanaannya. Karena itu, pers seharusnya bebas dari pengawasan dan pengaruh pemerintah. Itulah sebabnya di dalam masyarakat liberal, kemerdekaan pers dipandang sebagai suatu hal yang sangat pokok karena dari kemerdekaan pers yang tumbuh di suatu negara merupakan barometer dari kemerdekaan yang dimiliki oleh masyarakat. Karena itu sensor dipandang sebagai restriksi yang inkonstitusional terhadap kemerdekaan pers. Hal tersebut dipandang sebagai suatu pelanggaran terhadap prinsip atau gagasan "pers merdeka".

Ciri-ciri pers yang merdeka berdasarkan teori libertarian dapat diperinci sebagai berikut: publikasi bebas dari setiap penyensoran pendahuluan; penerbitan dan pendistribusian terbuka bagi setiap orang tanpa memerlukan izin atau lisensi; kecaman terhadap pemerintah, pejabat atau partai politik tidak dapat di pidana; tidak ada kewajiban mempublikasikan segala hal; publikasi "kesalahan" dilindungi sama halnya dengan publikasi kebenaran dalam hal-hal yang berkaitan dengan opini dan keyakinan; tidak ada batasan hukum terhadap upaya pengumpulan informasi untuk kepenting-

jakan, Vol. 2 No. 2, Tahun 2008, Jakarta: Departemen Hukum dan Hak Asasi Manusia, hlm. 19. 
an publikasi; dan wartawan punya otonomi profesional dalam organisasi mereka. ${ }^{23}$ Berdasarkan hal tersebut di atas maka sistem pers dan kebebasan pers di era reformasi dikategorikan pers liberal dari Fred S Siebert.

\section{Penutup}

Pada masa Orde Baru (1966-1998) pemerintah menitik beratkan pada aspek stabilitas politik dalam rangka menunjang pembangunan nasional. Regulasi mengenai pers diatur dengan Undang-undang No. 11 Tahun 1966 tentang Ketentuan-ketentuan Pokok Pers jo Undang-undang No. 4 Tahun 1967 jo Undang-undang No. 21 Tahun 1982 dan juga Peraturan Menteri Penerangan No. 1 Tahun 1984 tentang Surat Izin Usaha Penerbitan Pers (SIUPP) yang menghasilkan pers yang otoriter dengan kedok sistem pers Pancasila yaitu sistem pers yang otoriter, maka kebebasan pers sangat dikekang yaitu dengan cara breidel (pembatalan SIUPP) serta menjebloskan ke penjara mereka yang dianggap anti pemerintah. Sedangkan di era Reformasi (1998-sekarang), tuntutan reformasi hukum merupakan salah satu yang berembus demikian kuat sejak Mei 1998. Begitu pula halnya dalam bidang politik hukum termasuk kebebasan pers. Dalam keadaan ini lahirlah Undang-undang No. 40 Tahun 1999 tentang Pers yang dibuat oleh legislatif hasil pemilu yang dinilai sangat demokratis. Berdasarkan Undangundang No. 40 Tahun 1999 tentang Pers menjurus ke sistem pers liberal yaitu dengan adanya euforia kebebasan yang kebablasan karena tidak ada lagi ketentuan regulasi yang represif.

\section{Daftar Pustaka}

Amin, Daud Aidir. "Membangun Optimalisasi Kebebasan Pers di Tengah Konservatisme Penegakan Hukum". Jurnal IImiah Pusat Pengkajian dan Pengembangan Kebijakan. Vol. 2 No. 2. Tahun 2008. J akarta: Departemen Hukum dan Hak Asasi Manusia;

Handoyo, B Hestu Cipto. 2009. Hukum Tata Negara Indonesia. Yogyakarta: Atmajaya;

23 Krisna Harahap, Op.Cit., hlm. 5.
Harahap, Krisna. 2003. Pasang Surut Kemerdekaan Pers di Indonesia. Bandung: PT. Grafitri;

Hasan, M. Nur. "Tantangan Demokrasi di Indonesia", J urnal Aspirasi. Vol. 16 No. 1. Juli 2006. Magister Ilmu Hukum Trisakti;

Moertopo, Ali. 1982. Strategi Pembangunan Nasional. J akarta: CSIS;

Muis, Abdul. "Perlindungan Hukum Terhadap Kebebasan Pers Pada Masa Orde Baru Dan Era Awal Reformasi". Jurnal IImu Hukum Kanun. Vol. 10 No. 26. Tahun 2000. Banda Aceh: FH Universitas Syiah Kuala;

Nurhasan. "Pasang Surut Penegakan HAM dan Demokrasi di Indonesia", J urnal IImu Hukum Litigasi. Vol. 6 No. 2. Juni 2005. Bandung: FH Universitas Pasundan;

Priamarizki, Adhi. "Demokrasi dan Kebebasan Pers", Jurnal Sentris-Pusat Pengkaji Pers. Vol. 5 No. 1. Tahun 2008;

Poerwadaminta, WJ S. 1976. Kamus Umum Bahasa Indonesia. J akarta: Balai Pustaka;

Rachmadi, F. 1990. Perbandingan Sistem Pers. J akarta: Gramedia;

Sumali. "Urgensi TNI di Bingkai Konstitusi Dalam Perspektif Yuridis Politis", Jurnal Hukum Respublica. Vol. 3 No. 1. Tahun 2003. FH Universitas Lancang Kuning;

Susilastuti, DN. “Kebebasan Pers Pasca Orde Baru", J urnal IImu Sosial Dan IImu Politik (J SP). Vol. 4 No. 2. Tahun 2000. Yogyakarta: Fakultas IImu Sosial dan IImu Politik Universitas Gadj ah Mada;

Syatri, Mahdor. "Kebebasan Pers: Demokrasi vs Regulasi", Majalah Sriwijaya. Vol. 38 No. 2. Tahun 2004. Palembang: Pusat Penelitian Universitas Sriwijaya;

Tutuko, Joko dan Abdul Latif. "Reformasi Dan Kebebasan Pers: Respon Insan Pers Terhadap UU No. 40 Tahun 1999 Tentang Pers". Jurnal Publica. Vol. 4 No. 1. Tahun 2008. FISIP Universitas Muhammadiyah Malang;

Usamy, M. Djamil. “Kebebasan Pers dan kaitannya dengan Penegakan Hak Asasi Manusia", Jurnal IImu Hukum Kanun. Vol. 24 No. 9. Tahun 1999. Banda Aceh: Fakultas Hukum Universitas Syiah Kuala;

Usfunan, Johanes. "Jaminan dan perlindungan kebebasan Pers di Indonesia". Majalah ilmiah Kertha Wicaksana. Vol. 5 No. 9. Tahun 1999. Denpasar: Fakultas Hukum Universitas Warmadewa. 